\title{
The Age of Personalized Medicine-From Patients to Consumers
}

\author{
The Digital Environment, Clickwrap Contracts, \\ and Implications for Autonomy
}

Andelka M Phillips

As individuals, we all should be able to exercise our autonomy by making choices for ourselves. In the context of the practice of medicine, the principle of autonomy is one of the most significant ethical principles and respect for this principle is provided by the requirement to provide informed consent to undergo medical treatment and also the right of patients to refuse to undergo treatment. Our world today is experiencing rapid technological change, with many new products and services. This is the age of big data, Personalized and now Precision Medicine. It is also an age where many developments can be viewed as consumer-focused health-care services creating new markets, which challenge traditional paradigms, especially the paradigm of the doctor-patient relationship and the medical clinic, as the main providers of medical services. Many of these products and services are marketed and sold online to the public internationally, with little specific industry regulation. The mode of sale and lack of oversight mean that businesses often rely on their electronic contracts, available on their websites, to govern their relationships with their consumers. This chapter will explore the implications that the proliferation of electronic contracts and the designed environment of websites have on the exercise of individual autonomy when accessing services online. It does this in a specific context, that of Personalized Medicine, focusing on the example of direct-to-consumer genetic testing services (hereafter DTC, also referred to as personal genomics or commercial genomics), which have created a market for genetic tests as consumer services. ${ }^{1}$ Very few tests on the market have been approved by any regulatory body ${ }^{2}$ and their clinical utility is

${ }^{1}$ AM Phillips, Buying Your Self on the Internet: Wrap Contracts and Personal Genomics (Edinburgh University Press, 2019); AM Phillips, 'Reading the Fine Print When Buying Your Genetic Self Online: Direct-to-Consumer Genetic Testing Terms and Conditions' (2017) 36(3) New Genetics and Society 273-95, http://dx.doi.org/10.1080/ 14636778.2017.1352468 accessed 15 July 2019; AM Phillips, 'Genetics Goes Online-Privacy in the World of Personal Genomics' (October 2018), Privacy Laws \& Business International Report, 19-21; AM Phillips, 'Only a Click Away-DTC Genetics for Ancestry, Health, Love ... and More: A View of the Business and Regulatory Landscape' (2016) 8 Applied \& Translational Genomics 16-22, https://doi.org/10.1016/j.atg.2016.01.001 accessed 15 July 2019; and AM Phillips, 'Genomic Privacy and Direct-to-Consumer Genetics-Big Consumer Genetic Data-What's in that Contract?' (presented at GenoPri'15 (The 2nd Workshop on Genome Privacy and Security) and published as part of IEEE Conference Proceedings 2015), https://www.computer.org/csdl/proceedings/spw/ 2015/9933/00/9933a060.pdf accessed 15 July 2019.

2 23andMe, '23andMe Granted Authorization by FDA to Market First Direct-to-Consumer Genetic Test Under Regulatory Pathway for Novel Devices', Press Release (19 February 2015), https://mediacenter.23andme.com/ press-releases/fdabloomupdate/ accessed 15 July 2019; C Humer and J Steenhuysen, '23andME Launches New Consumer Test Service to Check for Genetic Disorders', Scientific American (2015), http://www.scientificamerican. com/article/23andme-launches-new-consumer-test-service-to-check-for-genetic-disorders/ accessed 15 July 
questionable. ${ }^{3}$ For instance, although 23 andMe has received approval from the US Food and Drug Administration (FDA) for a small number of its health tests, the approval for its BRCA testing came with a number of controls. This included the recommendation that consumers will need to have additional testing in a clinic before making decisions about treatment options. ${ }^{4}$ Furthermore, as these services are sold internationally, physical samples of DNA and genetic data generated from those samples is often being processed and stored in countries other than where the consumer resides. It should be noted that the UK House of Commons' Science and Technology Committee has launched an enquiry into commercial genomics in early $2019^{5}$ and we may see regulatory reform in the United Kingdom in light of this, but as the review will be completed after submission of this chapter, it is not possible to consider the Committee's recommendations herein.

Please note that this is an exploratory chapter; I am not purporting to be able to solve all the complex issues and challenges raised by consumerism of medicine. Instead, the aim herein is to draw attention to the manner in which interface design and electronic contracts can impact upon our abilities to make informed choices and exercise our autonomy. This chapter draws upon my related research, which included a review of the electronic wrap contracts of seventy-one companies that provide genetic tests for health purposes. ${ }^{6}$

\section{What Does Autonomy Mean?}

Autonomy is discussed in a number of other chapters in this book (see, for instance, the chapters by Thana C De Campos, Charles Foster, and Robert Gay). As Gay writes:

Respect for autonomy implies that a person can freely choose what should be done on his or her behalf, and have that choice respected or, at the very least, implies allowing the person to refuse that something be done to him or to her in the context of health care. We might suggest that a paradigm example of the application of this principle is the ethical and legal requirement for sufficient informed consent ...7

2019; US Food and Drug Administration, 'FDA Allows Marketing of First Direct-to-Consumer Tests that Provide Genetic Risk Information for Certain Conditions', Press Release (6 April 2017), https://www.fda.gov/newsevents/ newsroom/pressannouncements/ucm551185.htm accessed 15 July 2019.

\footnotetext{
${ }^{3}$ J Karow, '23andMe DTC Breast and Ovarian Cancer Risk Test Misses Almost 90 Percent of BRCA Mutation Carriers', GenomeWeb (5 April 2019), https://www.genomeweb.com/molecular-diagnostics/23andme-dtcbreast-and-ovarian-cancer-risk-test-misses-almost-90-percent-brca\#.XKfbrS1L1PU accessed 15 July. 2019; see Limitations of HBOC Direct-To-Consumer Genetic Screening: False Positives, False Negatives and Everything in Between' Abstract 27 presented at the ACMG Annual Clinical Genetics Meeting, 4th April 2019, Washington State Convention Center https://acmg.expoplanner.com/index.cfm?do=expomap.sess\&event_id=13\&session_ id $=10875$ accessed 3 August 2019.

${ }^{4}$ FDA, 'FDA Authorizes, with Special Controls, Direct-to-Consumer Test that Reports Three Mutations in the BRCA Breast Cancer Genes', FDA News Release (6 March 2018), https://www.fda.gov/NewsEvents/Newsroom/ PressAnnouncements/ucm599560.htm accessed 15 July 2019.

5 Science and Technology Committee (Commons), Commercial Genomic Inquiry (March 2019), https://www. parliament.uk/business/committees/committees-a-z/commons-select/science-and-technology-committee/inquiries/parliament-2017/commercial-genomics-17-19/ accessed 15 July 2019; please note that I am making a submission to this Committee and meeting with its chair.

${ }^{6}$ Seen 1.

7 See Chapter 1, this volume.
} 
Even when we are at our most vulnerable, we are still expected to exercise our autonomy by providing informed consent to appropriate treatment where it is offered. Although we do not have a right to demand any kind of medical treatment, we can decide not to undertake treatment. Although in some contexts we may favour a different approach from autonomy and when we consider issues of well-being relational autonomy has much to offer, informed consent is a useful requirement in the context of the practice of medicine.

In Thana de Campos's chapter in this volume (Chapter 5), she explores some of the critiques of autonomy. However, the focus herein is different. I am not advocating for giving autonomy prominence over any other ethical principle, but what I wish to do is to draw attention to the ways in which new services offered via the internet can influence our exercise of autonomy and our ability to make informed choices and provide informed consent. It is hoped that this work will encourage readers to think about how new and emerging consumer-focused health-care services offered online are framed and how we might need to do things differently. This is an important topic, because regardless of critiques, it is still generally accepted that an individual must give their consent to medical treatment and were a person to have a genetic test in a medical setting he or she would generally be required to provide informed consent prior to testing.

Furthermore, in the context of services that utilize personal data, in Europe especially, the General Data Protection Regulation (GDPR) sets a high standard for consent in the context of processing personal data. ${ }^{8}$ Under article 4 , genetic data is included within the definition of personal data and as DTC companies collect and process both genetic data and other forms of personal data, they should be complying with the provisions of the GDPR (it is also included in article 9 as discussed below). Consent is defined in article 4(11) as 'any freely given, specific, informed and unambiguous indication of the data subject's wishes by which he or she, by a statement or by a clear affirmative action, signifies agreement to the processing of personal data relating to him or her'. For UK citizens, the United Kingdom's Data Protection Act 2018 sets a similar standard ${ }^{9}$ and the United Kingdom's Information Commissioner's Office (ICO) has indicated that businesses marketing their services to UK consumers need to comply with both the GDPR and the Data Protection Act. ${ }^{10}$

Genetic data is also included under article 9 of the GDPR in the prohibition on processing of special categories of data. Article 9 provides for a number of exceptions to this prohibition, but in the context of DTC, the most relevant exceptions are the 'explicit consent' of the data subject as set out in article 9(2)(b) and the research exemption set out in article 9(2)(j). Although article 4(11) provides the general definition of consent to data processing, article 7 also imposes a number of conditions in relation to consent, including that where

the data subject's consent is given in the context of a written declaration which also concerns other matters, the request for consent shall be presented in a manner which is clearly distinguishable from the other matters, in an intelligible and easily accessible form, using

${ }^{8}$ Council Regulation (EU) 2016/679 of 27 April 2016 on the protection of natural persons with regard to the processing of personal data and on the free movement of such data, and repealing Directive 95/46/EC (General Data Protection Regulation), [2016] OJ 2 119/1, http://eur-lex.europa.eu/legal-content/EN/TXT/?qid=152527215 4893\&uri=CELEX:32016R0679 accessed 15 July 2019.

9 See Data Protection Act 2018, Pt 4, s 84, https://www.legislation.gov.uk/ukpga/2018/12/pdfs/ukpga 20180012_en.pdf accessed 15 July 2019.

10 See ICO, 'Guide to Data Protection', https://ico.org.uk/for-organisations/guide-to-data-protection/ accessed 15 July 2019. 
clear and plain language. Any part of such a declaration which constitutes an infringement of this Regulation shall not be binding.

Therefore, genetic testing services offered to individuals based in the European Union need to meet the GDPR's requirements for consent, and this is quite a high standard. Given the commercial nature of DTC services, it is also unlikely that they could rely on the research exception, although if they were able to use it, they would still need to meet the consent requirements for the initial genetic test and it is likely that a new consent would be required for any secondary research using consumers' data. As the GDPR is also exerting a strong influence on the reform of data protection law globally, with countries such as New Zealand, Singapore, Japan, and Brazil ${ }^{11}$ as well as others also reforming their law, it is likely that companies offering genetic testing services in other countries will also have to meet similar standards for consent.

The GDPR provides people with a number of rights in relation to their personal data and this also includes the right to erasure and the right to withdraw consent, which means that businesses handling personal data should also provide options for consumers to have their data deleted. While this may be challenging, DTC companies could provide an option for consumers to have their data deleted after a test is performed. Guardiome is an interesting example here, as they provide a whole genome-sequencing service, where their consumers receive their genomic sequence data on a device and at present Guardiome does not store or share their consumers' data. ${ }^{12}$ This example shows that it is possible for DTC companies to make their services more privacy friendly and it is hoped that other companies will start to provide more privacy-centred services.

In the United Kingdom, the Human Tissue Act 2004 (which is enforced by the Human Tissue Authority) governs the use of human tissue and organs and it also has applicability to genetic tests. Section 45 of the Act makes it a criminal offence to perform genetic analysis without appropriate consent. The Human Tissue Authority has also released guidance in the form of Codes of Practice on Consent and the latest version of its Code of Practice on Consent suggests that: 'commercial organisations offering services related to the removal, storage and use of human tissue and cells must ensure that materials provided to customers to aid their decision-making, such as marketing and advertising materials, are accurate and abide by the Advertising Standards Agency's guidelines. ${ }^{13}$ If we consider this in the

\footnotetext{
11 M Ramey, 'Brazil's New General Data Privacy Law Follows GDPR Provisions', Inside Privacy (20 August 2018), https://www.insideprivacy.com/international/brazils-new-general-data-privacy-law-follows-gdprprovisions/ accessed 15 July 2019 (the English version of the new Brazilian legislation is available at https://www. pnm.adv.br/wp-content/uploads/2018/08/Brazilian-General-Data-Protection-Law.pdf) accessed 15 July 2019; H Lovells, 'Changes in Japan Privacy Law to Take Effect in Mid-2017', LEXOLOGY (1 February 2017), https:// www.lexology.com/library/detail.aspx?g=efa0a2b0-b73e-456c-b4fa-26a268e9e751 accessed 15 July 2019; New Zealand Privacy Commissioner, 'Privacy Law Reform', https://www.privacy.org.nz/the-privacy-act-and-codes/ privacy-law-reform/ accessed 15 July 2019; 'Singapore Personal Data Protection Reforms in Force from Next Year', Out-Law (3 September 2018), https://www.out-law.com/en/articles/2018/september/singapore-personal-dataprotection-reforms/ accessed 15 July 2019.

12 Guardiome, https://www.guardiome.com/omics-lab accessed 10 September 2019; and T Ray and UG Thomas, 'Startup Guardiome Emphasizes Privacy in New WGS Consumer Offering', GenomeWeb (29 December 2015), https://www.genomeweb.com/sequencing-technology/startup-guardiome-emphasizes-privacy-new-wgsconsumer-offering\#.XLZXo3ZR1PU accessed 15 July 2019.

${ }^{13}$ See Phillips, Buying Your Self on the Internet (n 1) ch 3, citing Human Tissue Authority, 'Code A: Guiding Principles and The Fundamental Principle of Consent' (version updated 3 April 2017), 11, para 40, https://www. hta.gov.uk/hta-codes-practice-and-standards- 0 accessed 15 July 2019; the previous version of this code was substantially similar. See Human Tissue Authority, 'Code of Practice 1-Consent' (Version 14.0, updated July 2014),
} 
context of the provision of DTC genetic tests for health purposes, DTC companies should be making sure that both content on their websites and claims made in advertising are not misleading and are transparent about the respective risks, benefits, and limitations of testing. The need for unbiased marketing and transparency has also been stressed in much of the policy guidance on DTC to date. ${ }^{14}$ Websites can be useful platforms for providing consumers with helpful information about genetic testing, but there is much room for improvement here, as previous studies have raised concern over the manner in which information regarding the respective risks and benefits of testing is provided, ${ }^{15}$ together with the provision of information regarding companies' data privacy practices and consumers' understanding of that information. ${ }^{16}$

\section{The Example of Direct-to-Consumer Genetic Tests for Health Purposes}

The DTC industry is an interesting example, as it has created a new market for genetic tests, where people can order a genetic test from their homes without the involvement of a medical practitioner. The industry has developed over the last two decades ${ }^{17}$ and it offers a diverse range of tests, which include tests for a wide array of health conditions, ancestry, and more dubious tests, such as tests for child talent, paternity, and infidelity. ${ }^{18}$ Typically, a consumer will purchase the test online and then the company will send the consumer a sample collection kit, normally for a saliva sample or cheek swab. The consumer will the send this back to the company for analysis and receive test results through a web interface. It should be noted that the industry currently does not have harmonized standards and this applies to both tests for health purposes and ancestry testing. Therefore, it is possible to obtain contradictory disease risk estimates from different companies, ${ }^{19}$ and many tests currently offered

archived content available at https://web.archive.org/web/20170120025305/https://www.hta.gov.uk/sites/default/ files/Code_of_practice_1_-_Consent.pdf accessed 15 July 2019.

\footnotetext{
${ }^{14}$ See, for instance, Human Genetics Commission, 'A Common Framework of Principles for Directto-Consumer Genetic Testing Services' (Department of Health, 2010), archived content available at https://webarchive.nationalarchives.gov.uk/20120504102236/http://www.hgc.gov.uk/Client/document. asp?DocId=280\&CAtegoryId $=10$ accessed 15 July 2019; European Academies Science Advisory Council (EASAC) and the Federation of European Academies of Medicine (FEAM), 'Direct-to-Consumer Genetic Testing: Summary Document' (EASAC-FEAM Project on Direct-to-Consumer Genetic Testing, October 2012), https://www.easac.eu/fileadmin/PDF_s/reports_statements/Easac_12_DTCGT-Lay_Web.pdf accessed 15 July 2019; European Society of Human Genetics, 'Statement of the ESHG on Direct-to-Consumer Genetic Testing for Health-Related Purposes' (2010) 18(12) European Journal of Human Genetics 1271-73.

15 A Singleton, LH Erby, KV Foisie, et al, 'Informed Choice in Direct-to-Consumer Genetic Testing (DTCGT) Websites: A Content Analysis of the Benefits, Risks, and Limitations' (2012) 21(3) Journal of Genetic Counseling 433-9; JA Hall, R Gertz, J Amato, et al, 'Transparency of Genetic Testing Services for "Health, Wellness and Lifestyle": Analysis of Online Prepurchase Information for UK Consumers' (2017) 25(8) European Journal of Human Genetics 908-17.

${ }^{16}$ E Christofides and K O’Doherty, 'Company Disclosure and Consumer Perceptions of the Privacy Implications of Direct-to-Consumer Genetic Testing' (2016) 35(2) New Genetics and Society 101-23; J Hazel and C Slobogin, 'Who Knows What, and When?: A Survey of the Privacy Policies Proffered by U.S. Direct-to-Consumer Genetic Testing Companies' (19 April 2018, last revised 18 October 2018), Cornell Journal of Law and Public Policy and Vanderbilt Law Research Paper No 18, https://ssrn.com/abstract=3165765 accessed 15 July 2019.

17 S Hogarth and P Saukko, 'A Market in the Making: The Past, Present and Future of Direct-to-Consumer Genomics' (2017) 36(3) New Genetics and Society 197-208, 197.

18 Phillips, 'Reading the Fine Print' (n 1).

19 US Government Accountability Office, (GAO) Direct-To-Consumer Genetic Tests: Misleading Test Results Are Further Complicated by Deceptive Marketing and Other Questionable Practice (GAO-10-847T,
} 
may require further confirmatory testing in a clinic before decisions can be made about a particular individual's treatment. A recent study by Esplin et al found that 23andMe's BRCA test 'misses almost 90 percent of BRCA mutation carriers, both in those with and those without a personal or family history of cancer. ${ }^{20}$ While this study was focused on clinical utility, the authors questioned how useful overall such testing was for individuals with genuine health concerns, given that both those who receive positive and those who negative test results would require further testing to confirm their results. It should be noted that it is also possible to obtain contradictory ethnicity estimates. ${ }^{21}$

While the focus herein is on DTC tests for health purposes and these services together with DTC ancestry tests have received the bulk of academic attention to date, it should be stressed that most DTC companies are not restricted to offering only one type of test. While there remains a lack of industry-specific oversight, this also allows unscrupulous entities to operate. For example, it has recently emerged that vulnerable groups have been targeted in Louisville, Kentucky, where vans have driven to some of the most impoverished neighbourhoods and offered individuals $\$ 20$ for cheek swabs of DNA. ${ }^{22}$ In response to this, Kentucky's Attorney General has now issued a scam alert and it appears that this scam together with another is targeted towards identity theft and Medicaid fraud. ${ }^{23}$ I also wish to stress that while less attention has been devoted to more dubious types of tests, such as those for child talent, 'peace of mind' paternity, and infidelity, we do need more research on these tests and regulators should play a role in protecting the public from these services.

Furthermore, several of the most prominent DTC companies are engaging in secondary health research using data collected from consumers. ${ }^{24}$ Companies are also increasingly partnering with other entities in order to conduct medical research with $23 \mathrm{andMe}$, entering

2010) Testimony before the Subcommittee on Oversight and Investigations, Committee on Energy and Commerce, House of Representatives, 1-8, http://www.gao.gov/assets/130/125079.pdf accessed 15 July 2019; J Cussins, 'Direct-to-Consumer Genetic Tests Should Come with a Health Warning', Pharmaceutical Journal (15 January 2015), https://www.pharmaceutical-journal.com/opinion/comment/direct-to-consumer-genetic-testsshould-come-with-a-health-warning/20067564.article?firstPass=false accessed 15 July 2019.

20 J Karow, '23andMe DTC Breast and Ovarian Cancer Risk Test Misses Almost 90 Percent of BRCA Mutation Carriers', GenomeWeb (5 April 2019), https://www.genomeweb.com/molecular-diagnostics/23andme-dtcbreast-and-ovarian-cancer-risk-test-misses-almost-90-percent-brca\#.XKfbrS1L1PU accessed 15 July 2019.

${ }^{21}$ KV Brown, 'How DNA Testing Botched My Family's Heritage, and Probably Yours, Too' GIZMODO (16 January 2018), https://gizmodo.com/how-dna-testing-botched-my-familys-heritage-and-probab-1820932637 accessed 15 July 2019; see also WD Roth and B Ivemark, 'Genetic Options: The Impact of Genetic Ancestry Testing on Consumers' Racial and Ethnic Identities' (2018) 124(1) American Journal of Sociology 150-84; WD Roth, 'Genetic Ancestry Tests Don't Change Your Identity, But You Might', The Conversation (5 July 2018), https:// theconversation.com/genetic-ancestry-tests-dont-change-your-identity-but-you-might-98663 accessed 15 July 2019.

${ }^{22}$ P Ashley, 'Residents Concerned about DNA-for-Cash Transactions in Louisville', Wave 3 News (1 April 2019), http://www.wave3.com/2019/04/01/residents-concerned-about-dna-for-cash-transactions-louisville/ accessed 15 July 2019.

${ }^{23}$ Office of the Attorney General of Kentucky, 'Beshear: Fraudulent Medical Billing Scams Targeting Kentuckians', Scam Alert (9 April 2019), https://ag.ky.gov/scams/Pages/Current-Scam-Alert.aspx accessed 15 July 2019; 'Kentucky AG on DNA-for-Cash Scheme', GenomeWeb (12 April 2019), https://www.genomeweb. com/scan/kentucky-ag-dna-cash-scheme\#.XLUk5i9L10s accessed 15 July 2019; M Glowicki, 'Beshear Urges Those Who Received Money for DNA Samples to Call Fraud Hotline', Louisville Courier Journal (8 April 2019), https://www.courier-journal.com/story/news/crime/2019/04/08/kentucky-ag-asks-dna-cash-customers-callfraud-hotline/3405027002/ accessed 15 July 2019; KV Brown, 'Scammers May Be Using DNA Testing to Defraud Medicare and Steal Identities', Bloomberg (18 April 2019), https://www.bloomberg.com/news/articles/2019-04-17/ scam-dna-tests-may-be-new-target-for-health-fraud-states-warn accessed 15 July 2019.

${ }_{24}$ AM Phillips, 'Only a Click Away-DTC Genetics for Ancestry, Health, Love ... and More: A View of the Business and Regulatory Landscape’ (2016) 8 Applied \& Translational Genomics 16-22. 
into at least fifteen partnerships to date ${ }^{25}$ (the most recent being with GlaxoSmithKline ${ }^{26}$ ) and Orig3n entering a partnership with the Chinese insurer ZhongAn Online P\&C Insurance Co, $\mathrm{Ltd}{ }^{27}$ Thus, there is real potential for data sharing in this context and companies marketing their services to EU consumers do have work to do in order to ensure compliance with the GDPR.

Prior to the advent of DTC services, genetic tests for health purposes were only offered in a clinical setting and, today, if a patient undergoes a genetic test in a clinic, as well as having to provide informed consent to undergo testing, they will also have genetic counselling both prior to and after the test. This counselling assists patients in understanding what test results mean for them, including the limitations of such tests. While a number of genetic tests are useful in clinical practice, there is a lack of validation and clinical utility for many tests for common, complex diseases. ${ }^{28}$ Concern has been expressed regarding the limitations of tests. One of the reasons for this is that tests have not been standardized for many complex diseases and it is possible to obtain contradictory risk estimates for the same disease or condition from different companies. ${ }^{29}$ Recent research has also found a relatively high level of false positive results in DTC offerings ${ }^{30}$ and concern has also been expressed regarding the nature of information provided by DTC companies about their services. ${ }^{31}$

${ }^{25}$ M Sullivan, '23andMe Has Signed 12 Other Genetic Data Partnerships beyond Pfizer and Genentech', VentureBeat (14 January 2015), https://venturebeat.com/2015/01/14/23andme-has-signed-12-other-geneticdata-partnerships-beyond-pfizer-and-genentech/ accessed 15 July 2019; C Lagorio-Chafkin, '23andMe Exec: You Ain't Seen Nothing Yet', Inc (7 January 2015), http://www.inc.com/christine-lagorio/23andMe-new-partnerships. html accessed 15 July 2019.

${ }^{26}$ L Geggel, '23andMe Is Sharing Its 5 Million Clients' Genetic Data with Drug Giant GlaxoSmithKline', Livescience (26 July 2018), https://www.livescience.com/63173-23andme-partnership-glaxosmithkline.html accessed 15 July 2019; GlaxoSmithKline, 'GSK and 23andMe Sign Agreement to Leverage Genetic Insights for the Development of Novel Medicines' (25 July 2018), https://www.gsk.com/en-gb/media/press-releases/gsk-and23andme-sign-agreement-to-leverage-genetic-insights-for-the-development-of-novel-medicines/ accessed 15 July 2019.

${ }^{27}$ S Hurst, 'Chinese E-Insurer Zhong An Has Teamed Up with BioTech Company Orig3n for Health Tech Solutions', CROWDFUND INSIDER (2 August 2018), https://www.crowdfundinsider.com/2018/08/137259chinese-e-insurer-zhongan-has-teamed-up-with-biotech-company-orig $3 \mathrm{n}$-for-health-tech-solutions/ accessed 15 July 2019.

${ }^{28}$ A Regalado, '23andMe Thinks Polygenic Risk Scores Are Ready for the Masses, But Experts Aren't So Sure, MIT Technology Review (8 March 2019), https://www.technologyreview.com/s/613095/23andme-thinkspolygenic-risk-scores-are-ready-for-the-masses-but-experts-arent-so-sure/ accessed 15 July 2019; MC Cornel, CG van El, and P Borry, 'The Challenge of Implementing Genetic Tests with Clinical Utility While Avoiding Unsound Applications' (2014) 5(1) Journal Community Genetics 7-12; JP Annes, MA Giovanni, and MF Murray, 'Risks of Presymptomatic Direct-to-Consumer Genetic Testing' (2010) 363 New England Journal of Medicine $1100-1$.

${ }^{29}$ US Government Accountability Office, 'Direct-To-Consumer Genetic Tests: Misleading Test Results Are Further Complicated by Deceptive Marketing and Other Questionable Practice', GAO-10-847T (2010), https:// www.gao.gov/products/GAO-10-847T accessed 15 July 2019.

${ }^{30}$ S Tandy-Connor, J Guiltinan, K Krempely, et al, 'False-Positive Results Released by Direct-to-Consumer Genetic Tests Highlight the Importance of Clinical Confirmation Testing for Appropriate Patient Care' (2018) 20 Genetics in Medicine 1515-21.

${ }^{31}$ NP Lewis, D Treise, SI Hsu, et al, 'DTC Genetic Testing Companies Fail Transparency Prescriptions' (2011) 30 New Genetics and Society 291-307; LI Laestadius, JR Rich, and PL Auer, 'All Your Data (Effectively) Belong to Us: Data Practices among Direct-to-Consumer Genetic Testing Firms' (2016) 19 Genetics in Medicine 513-20; J Hazel and C Slobogin, 'Who Knows What, and When?: A Survey of the Privacy Policies Proffered by U.S. Directto-Consumer Genetic Testing Companies' (19 April 2018, last revised 18 October 2018), Cornell Journal of Law and Public Policy and Vanderbilt Law Research Paper No 18-18, https://ssrn.com/abstract=3165765 accessed 15 July 2019. 


\section{Consent and Contracting Online}

As noted above, DTC services can be viewed as one example of Personalized Medicine. Personalized Medicine encompasses many things, but a useful way of conceptualizing it is that these are innovations that are centred around tailoring treatment to individuals, rather than diseases. ${ }^{32}$ Meanwhile, Precision Medicine goes one step further and can be described as 'an emerging approach for disease treatment and prevention that takes into account individual variability in genes, environment, and lifestyle for each person. ${ }^{33}$ While the idea of Personalized Medicine has broad appeal, the reality of tailoring medical treatment to individuals in reality is far more challenging, and as Dickenson et al write: 'it is extremely unlikely that completely individualized treatments are ever going to be feasible. Many commentators and clinicians acknowledge that the best aspiration is to deliver diagnoses and treatments stratified into patient groups by genomic science. ${ }^{34}$ Nevertheless, services such as DTC genetic tests challenge both doctor-patient relationships and the very nature of how medical services are offered. In the context of medical treatment, an individual is no longer solely a patient: he or she may also be a consumer simultaneously. Doctors can also be seen as service providers. This has also expanded the range of entities that provide health and medical services and the lines between what distinguishes medical services from other types of services are beginning to blur. This raises a number of difficult issues, but the aim herein is to shed light on how our autonomy as individuals is impacted by developments in consumer-focused health care. Sometimes, the services offered may not be new in themselves, but the mode of access is different. For others, though, the service itself may be novel. While the focus herein is on the example of DTC genetic tests, wearable devices, such as smart watches and fitness bands, raise similar issues.

The internet is increasingly an integral part of everyday life for many people. Most of us will use it for both work and leisure. However, what is often overlooked is that the way in which the internet and e-commerce have evolved to date has given increased prominence to contract law in regulating relationships between companies and consumers and also in regulation of new products and services, where industry-specific legislation is lacking. Whether you are visiting a website, installing software, or purchasing a product or service online, you are forming contractual relationships. Every website you encounter will have its own contract in the form of terms of use, terms of service, or terms and conditions. These are electronic contracts, typically clickwrap or browsewrap, which have evolved from shrinkwrap licences. They are also mass standard form contracts (sometimes referred to as boilerplate) and are also forms of contracts of adhesion. ${ }^{35}$ A clickwrap contract will usually display the terms of the contract on the screen and require the user to scroll through the terms before clicking on a button, which may be labelled 'I Agree' or 'I Accept'. In contrast, browsewrap contracts have the document title as a hyperlink without the terms displaying on the screen, meaning that it is possible to accept the terms without seeing them. ${ }^{36}$

\footnotetext{
32 J Herring, Medical Law and Ethics (7th edn, Oxford University Press, 2018), 12.

33 US National Library of Medicine, 'What Is Precision Medicine?', Genetics Home Reference, https://ghr.nlm. nih.gov/primer/precisionmedicine/definition accessed 15 July 2019.

34 D Dickenson, B van Beers, and S Sterckx, 'Introduction' in B van Beers, S Sterckx, and D Dickenson (eds), Personalised Medicine, Individual Choice and the Common Good (Cambridge University Press, 2018), 3.

35 NS Kim, Wrap Contracts: Foundations and Ramifications (Oxford University Press, 2014), 39-44; NS Kim, 'Exploitation by Wrap Contracts-Click “Agree”' (2014) 39(2) California Bar IP Journal, New Matter 10-17.

36 NS Kim, Wrap Contracts: Foundations and Ramifications (Oxford University Press, 2014), 41-4.
} 
Consider your own interaction with websites. Very few of us will have read all the terms of all the contracts we encounter online. We are also unlikely to have read all the privacy policies we encounter and as these documents are often linked together and seek to incorporate terms by reference, this is problematic. It means that in order to understand our rights and obligations in the context of a particular transaction with a business online, we should have, in fact, read all of these documents.

A number of studies have investigated the amount of contracts and privacy policies individuals encounter online, together with the time it would take to read these documents, as well as the readability of these documents. A few examples are discussed below to highlight the nature of people's interactions with these documents. Cranor and McDonald's 2008 study estimated that it would take 201 hours a year for the average American consumer to read all the privacy policies they encountered online. ${ }^{37}$ As more people are now accessing a greater number of services online, this figure is now likely to have increased.

The Norwegian Consumer Council (NCC) in its APPFAIL campaign estimated that the average smartphone contained 250,000 words of contracts or privacy policies. ${ }^{38}$ The NCC's APPFAIL report examined the contracts and privacy policies of twenty popular smartphone applications in order to assess their compliance with EU data protection and consumer protection law. This report included discussion of the issue of informed consent, and the NCC suggested that: 'If terms are very difficult to read as they are very long, ambiguous or written in overly technical, complex or vague language, a strong case can be made that informed consent is not possible for most consumers. ${ }^{39}$ Other studies have identified similar problems in relation to the length of contracts encountered by consumers. For example, according to Quartz, those who own five Apple devices will have entered into 'at least 30 contracts, totalling more than 100,000 words. ${ }^{40}$ Meanwhile, the work of the Australian consumer group CHOICE, which investigated the contracts of e-readers, using the example of the Kindle found that the device contained eight documents, which when combined exceeded 73,000 words in length and took the actor they hired to read them 9 hours to read aloud. ${ }^{41}$ While this may not seem problematic for products that are trivial, when they relate to more sensitive products and services, more caution is needed.

37 AM McDonald and LF Cranor, 'The Cost of Reading Privacy Policies' (2008) 4 Journal of Law and Policy for the Information Society 543-68; and see their more recent related work: JR Reidenberg, T Breaux, LF Cranor, et al, 'Disagreeable Privacy Policies: Mismatches between Meaning and Users' Understanding' (2015) 30 Berkeley Technology Law Journal 39-88; and F Schaub, R Balebako, and LF Cranor, 'Designing Effective Privacy Notices and Controls' (2017) 21 IEEE Internet Computing 70-7.

38 See Phillips, Buying Your Self on the Internet (n 1) ch 1, citing Norwegian Consumer Council, '250,000 Words of App Terms and Conditions' (24 May 2016), https://www.forbrukerradet.no/side/250000-words-of-app-termsand-conditions/ accessed 15 July 2019; Norwegian Consumer Council, 'APPFAIL Threats to Consumers in Mobile Apps' (March 2016), https://www.forbrukerradet.no/undersokelse/2015/appfail-threats-to-consumers-inmobile-apps/ accessed 15 July 2019.

39 Phillips, Buying Your Self on the Internet (n 1) ch 4, citing NCC (n 38) 24.

40 C Groskopf, 'CLICK “I AGREE” Apple Fans Have Click-Signed More than 100,000 Words of Legal Contracts', Quartz (5 November 2016), https://qz.com/797928/apple-fans-have-click-signed-more-than-100000-words-oflegal-contracts/ accessed 15 July 2019. This is also mentioned in the chapter AM Phillips, 'Will My Genes Really Help Me Fit into Those Jeans? Personal Genomics and Wrap Contracts' in L Edwards, B Schafer, and E Harbinja (eds), Future Law: Emerging Technology, Ethics and Regulation (forthcoming, Edinburgh University Press, 2020).

${ }^{41}$ E Hunt, 'Amazon Kindle's Terms "Unreasonable" and Would Take Nine Hours to Read, Choice Says', The Guardian (15 March 2017), https://www.theguardian.com/australia-news/2017/mar/15/amazon-kindles-termsunreasonable-and-would-take-nine-hours-to-read-choice-says accessed 15 July 2019; CHOICE, 'Nine Hours of "Conditions Apply"', https://www.choice.com.au/about-us/media-releases/2017/march/nine-hours-ofconditions-apply accessed 15 July 2019. The videos are available at https://www.youtube.com/watch?v=6QZml7sP bVU\&feature=youtu.be accessed 15 July 2019. 


\section{How Can We Exercise Our Autonomy When Behaving as Automatons?}

In their book Re-Engineering Humanity, Frischmann and Selinger suggest that contracts are often designed so as to blend into the website to enable a seamless transaction and that this has an impact on the ability of an individual to make an informed choice about whether or not to use these services. As they write:

Designers arrange the digital contracting environment to create a practically seamless, transaction cost minimized user experience. Rather than requiring people who intend to use online services to read lengthy pages filled with boilerplate legal jargon ... a simple click of the mouse, with mere conspicuous notice of the existence of terms suffices to manifest consent for entering legally binding contractual relationships. ${ }^{42}$

They 'claim that the electronic contracting environment should be understood as a technosocial tool for engineering human beings to behave automatically, like simple machines. ${ }^{23}$ Meanwhile, the NCC in their 2018 Deceived by Design report discuss the issue of nudging and the use of dark patterns in interface design, which steer users towards choosing less privacy-friendly options. ${ }^{44}$ Dark patterns is a term coined by Harry Brignull. ${ }^{45}$ NCC characterizes these as exploitative design choices, which can 'push consumers toward choices that benefit the service provider. ${ }^{46}$ Dark patterns are also 'ethically problematic, because they mislead users into making choices that are not in their interest, and deprive them of their agency.47 It should be noted that in April 2019, a US bill entitled the Deceptive Experiences to Online Users Reduction (DETOUR) Act was proposed, which would ban certain some of these practices if passed. ${ }^{48}$ This legislation if it is enacted could assist with improving how businesses operate in this context, but as it is currently framed it would only apply to organizations, which had more than 100 million users and this legislation would be much more beneficial for the public if this figure was lowered.

The idea that in the online environment we may in fact have decreased agency due to certain design features has increased significance when we consider new services, such as DTC, that are complex. Consider the difference between an individual purchasing a DTC test online without any involvement of a medical practitioner and the experience of an individual undergoing genetic testing in a clinic with access to support from both genetic counsellors and physicians. If there was no question of disparity of information or understanding in this

\footnotetext{
42 BM Frischmann and E Selinger, Re-Engineering Humanity (Cambridge University Press, 2018), 60; see also BM Frischmann and E Selinger, 'Engineering Humans with Contracts' (September 2016), Cardozo Legal Studies Research Paper No 493, https://papers.ssrn.com/sol3/papers.cfm?abstract_id=2834011 accessed 15 July 2019.

${ }_{43}$ Frischmann and Selinger, Re-Engineering Humanity (n 42) 61.

44 NCC, 'Deceived by Design' (June 2018), https://www.forbrukerradet.no/undersokelse/noundersokelsekategori/deceived-by-design/ accessed 15 July 2019.

${ }^{45}$ Phillips, Buying Your Self on the Internet (n 1) ch 5; citing Dark Patterns, 'What Are Dark Patterns?', https:// darkpatterns.org/ accessed 15 July 2019.

46 NCC (n 44) 4.

47 Ibid 7.

48 Please see S. 1084: Deceptive Experiences To Online Users Reduction Act https://www.govtrack.us/congress/ bills/116/s1084/text accessed 10 September 2019; see also Andelka M Phillips, 'All Your Data Will Be Held Against You: Secondary Use of Data from Personal Genomics \& Wearable Tech' in Susan Sterett and Lee Demetrius Walker (eds), Research Handbook On Law And Courts (Edward Elgar Publishing, forthcoming October 2019).
} 
context, we might not think about this in the same way, but we have developed governance mechanisms in medical law in order to protect patients and ensure high standards in the provision of medical services. Even in other situations where products and services sold online are of a less complex nature, we are starting to see a shift in how regulators and the public view interface design. Concern over the impact of screen use and addictive elements in application design are leading to calls for improved oversight and changing the way we do things. ${ }^{49}$ This is timely, and I should suggest that it should also be seen as an opportunity. New services and products offered online have evolved in a particular manner, but that does not mean this is the only way things could be done. DTC companies that wish to do respected and responsible medical research and want to retain consumer trust should consider how they can truly achieve compliance with applicable law, such as the GDPR, but also how to help their consumers. Interfaces could be designed that allow for speed bumps to slow the process of decision making down, rather than rushing consumers into a purchase.

\section{What Exactly Are You Agreeing To?}

A number of experiments that have involved the inclusion of problematic clauses in order to assess how people interact with these contracts further highlight both consumers' lack of reading of electronic contracts and the types of things that companies could bury in their fine print. These range from Purple's Community Service clause, which involved 1,000 hours of community service, including requirements to clean public toilets and hug strangers, ${ }^{50}$ to GameStation's Immortal Soul clause, ${ }^{51}$ or F-Secure's Herod clause. ${ }^{52}$ In the Purple example: 'All users were given the chance to flag up the questionable clause in return for a prize, but remarkably only one individual, which is $0.000045 \%$ of all Wi-Fi users throughout the whole two weeks managed to spot it. ${ }^{53}$ In the GameStation example, which

49 See eg the work of T Harris, 'How Technology Is Hijacking Your Mind-From a Magician and Google's Design Ethicist', Thrive Global (19 May 2016), https://www.thriveglobal.com/stories/8466-how-technology-is-hijackingyour-mind-from-a-magician-and-google-design-ethicist accessed 15 July 2019; see also Harris's website for other papers, http://www.tristanharris.com/essays/ accessed 15 July 2019; see also Center for Humane Technology, http://humanetech.com accessed 15 July 2019; and A Atler, Irresistible: The Rise of Addictive Technology and the Business of Keeping Us Hooked (Penguin, 2017), ch 1; see also S Collins, 'Call for Guidelines on Children's Screen Use', The New Zealand Herald (2 April 2019), https://www.nzherald.co.nz/national-video/news/video. cfm?c_id=1503075\&gal_cid=1503075\&gallery_id=205318 accessed 15 July 2019; and S Weale, 'Experts Call for Official Guidelines on Child Screen Use', The Guardian (25 December 2016), https://www.theguardian.com/society/2016/dec/25/experts-call-for-official-guidelines-on-child-screen-use accessed 15 July 2019; H Chowdhury, “'Addictive” Messenger Kids App Gives Children as Young as 6 New Way to Initiate Friend Requests', The Telegraph (14 August 2018), https://www.telegraph.co.uk/technology/2018/08/14/addictive-facebook-messenger-kidsapp-children-young-6-add-friends/ accessed 15 July 2019; S Gibbs, 'Apple Investors Call for Action over iPhone "Addiction" among Children', The Guardian (8 January 2018), https://www.theguardian.com/technology/2018/ jan/08/apple-investors-iphone-addiction-children accessed 15 July 2019; 'China Regulator to Set Time Limits on Hot Short-Video Apps', Bloomberg (29 March 2019), https://www.bloomberg.com/news/articles/2019-03-29/ china-regulator-to-set-time-limits-on-popular-short-video-apps accessed 15 July 2019.

50 See Phillips, Buying Your Self on the Internet (n 1) ch 1, citing Purple, '22,000 People Willingly Agree to Community Service in Return for Free WiFi' (13 July 2017), https://purple.ai/blogs/purple-community-service/ accessed 15 July 2019.

51 M Perton, 'Read Fine Print or GameStation May Own Your Soul', Consumerist (16 April 2010), http://consumerist.com/2010/04/16/read-fine-print-or-gamestation-may-own-your-soul/ accessed 15 July 2019.

52 T Fox-Brewster, 'Londoners Give Up Eldest Children in Public Wi-Fi Security Horror Show', The Guardian (29 September 2014).

53 D Tuffley, 'How Not to Agree to Clean Public Toilets When You Accept Any Online Terms and Conditions', The Conversation (23 July 2017), https://theconversation.com/how-not-to-agree-to-clean-public-toilets-whenyou-accept-any-online-terms-and-conditions-81169 accessed 15 July 2019. 
was actually a prank for April Fool's Day, the immortal soul clause included an opt out. Those who ticked the box to opt out were to receive a $£ 5$ voucher. ${ }^{54}$ However, only around 12 per cent of GameStation's customers opted out, meaning that more than 80 per cent failed to read the clause. ${ }^{55}$ Obar and Oeldorf-Hirsch also included a child assignment clause in their recent research on undergraduate students' interaction with the contract and privacy policy of a fictitious social network. ${ }^{56}$ In Obar and Oeldorf-Hirsch's study, a mere 1.7 per cent ( 9 out of 543) of those surveyed 'mentioned the child assignment clause. ${ }^{57}$ Obar and Oeldorf-Hirsch found that a sense of information overload may also be having an impact on how people engage with these policies online. ${ }^{58}$

In my review of seventy-one contracts from companies that provide DTC tests for health purposes, a number of contractual terms were identified which are problematic from a consumer protection perspective and could potentially be challenged on the grounds of unfairness under UK and EU consumer protection legislation. ${ }^{59}$ These included: clauses that permit the DTC company a broad power to alter the terms of their contract without notice to the consumer (unilateral alteration clause); together with clauses that deemed consent to acceptance of terms through use of the service or visiting the website. I have suggested elsewhere that such terms are challengeable under both EU and UK law on the grounds of unfairness. ${ }^{60}$ In the context of DTC specifically, clauses that allow a company broad power to alter terms without notice to the consumer are particularly problematic, given the sensitive nature of these services. These clauses can also lead to uncertainty regarding the exact content of the contract in its entirety, as where terms can change at any time it will be difficult for the consumer to have any certainty about what the terms of the contract are. As contracts also often refer to privacy policies, clauses of this type are also likely to be problematic from a data protection standpoint. In relation to clauses that deem consent to terms or privacy policies through either use of the service or visiting the website, these are also problematic from both consumer protection and data protection perspectives. It is unlikely that deeming consent through visiting a website or using a service will comply with the consent requirements set by the GDPR. Furthermore, consent to altered terms is also often deemed through continued use of the service or the website and this is also unlikely to be deemed as compliant with the GDPR.

A further issue in this context is the language used in online wrap contracts and privacy policies and how this impacts upon the exercise of autonomy and the ability of a consumer to make an informed choice. Becher and Benoliel's recent study assessed the readability of the wrap contracts used by 500 of the most popular American websites. ${ }^{61}$ Their results suggest that most of these contracts are not readable by the average consumer with most being

\footnotetext{
54 Perton (n 50).

55 J Brownlee, 'GameStation EULA Collects 7,500 Souls from Unsuspecting Customers', Geek.com (16 April 2010), https://www.geek.com/games/gamestation-eula-collects-7500-souls-from-unsuspecting-customers1194091/ accessed 15 July 2019.

56 JA Obar and A Oeldorf-Hirsch, 'The Biggest Lie on the Internet: Ignoring the Privacy Policies and Terms of Service Policies of Social Networking Services’ [2018] Information, Communication \& Society 1.

57 Ibid.

58 Ibid.

59 Phillips, 'Reading the Fine Print' (n 1) 273-95; see also Phillips, Buying Your Selfon the Internet (n 1) ch 5.

${ }^{60}$ Ibid.

${ }^{61}$ U Benoliel and SI Becher, 'The Duty to Read the Unreadable' (January 11, 2019) 60 Boston College Law Review 1-37 Forthcoming, available at SSRN: https://ssrn.com/abstract=3313837 or http://dx.doi.org/10.2139/ ssrn. 3313837
} 
written in language similar to that of academic journal articles. ${ }^{62}$ Other work by Conklin and Hyde, which investigated the readability of insurance policies found that of seven policies considered, 'the easiest requiring 14 years of education and the most difficult requiring a PhD-level education. ${ }^{3}$ If we consider this in the context of the provision of DTC genetic tests for health purposes, which are complex in nature, there is a significant likelihood that consumers would have difficulty understanding the language used in these contracts even if they have time to read them and this should support the need for reform of governance of this industry, especially in relation to contracts and privacy policies, but also in relation to the provision of information about DTC tests.

\section{Repurposing Genetic Data}

The example of DTC is useful here as it demonstrates some of the ways in which our personal information can be repurposed. Privacy is a significant issue in this context, as once an individual undergoes a genetic test, the results of that test in the form of digitized genetic data can be stored potentially indefinitely. They can also serve as a unique identifier for the individual and also be used to trace family members. For example, a number of DTC companies offer family-finder features in their ancestry testing services, which can connect individuals with unknown relatives and lead to significant revelations, such as unknown paternity. A recent news article discussed the experience of a woman who, through using 23andMe, found out not only about her biological donor father's genetic profile, but a large number of siblings (a total of thirty siblings), some of whom did not know they were donor conceived before using 23 andMe's service. ${ }^{64}$ While for some people, this may be a positive experience, it is also something that can have a very significant impact on individuals and there needs to be more information provided to the public regarding this.

In 2018, there was also much press coverage of the use of the genetic genealogy database GEDmatch in the investigation for the Golden State Killer case. ${ }^{65}$ It is important to understand that GEDmatch is not a DTC company, but a database that allows users to upload genetic data from other services. It previously allowed for this type of use by law enforcement in its site user policy, but it should be noted that it changed this policy in May 2019, opting its users out of law enforcement matching by default. ${ }^{66}$ In the Golden State Killer

62 Ibid at 21.

63 Phillips, Buying Your Self on the Internet (n 1) 7, citing K Conklin and R Hyde, 'If small print 'terms and conditions' require a PhD to read, should they be legally binding?' The Conversation (10 May 2018) https:// theconversation.com/if-small-print-terms-and-conditions-require-a-phd-to-read-should-they-belegallybinding-75101 accessed 10 September 2019; see also K Conklin, R Hyde, and F Parente, 'Assessing plain and intelligible language in the Consumer Rights Act: a role for reading scores?' (2018) Legal Studies ISSN 1748-121X (in Press) http://eprints.nottingham.ac.uk/51073/ accessed 10 September 2019.

64 'Only Sort of an Only Child' (1 April 2019), https://www.genomeweb.com/scan/only-sort-only-child accessed 15 July 2019; see A Hassan, '2 Bay Area Women Linked to 28 Siblings Following DNA Test', ABC (30 March 2019), https://abc7news.com/society/2-bay-area-women-linked-to-28-siblings-following-dna-test/5225970/ accessed 15 July 2019.

65 AM Phillips, 'Genetics Goes Online-Privacy in the World of Personal Genomics', PL\&B International (October 2018), http://www.andelkamphillips.com/wp-content/uploads/2018/10/Genetics.pdf accessed 10 September 2019.

66 Adam Vaughan, 'DNA database opts a million people out from police searches' New Scientist (20 May 2019) https://www.newscientist.com/article/2203857-dna-database-opts-a-million-peopleout-from-policesearches/ accessed 21 June 2019. 
investigation, law enforcement created a profile on GEDmatch in order to find relatives of a potential suspect based on DNA samples collected at crime scenes some thirty years earlier. Through the use of the database, a suspect, James DeAngelo, was subsequently arrested and proceedings are ongoing. ${ }^{67}$ It should be noted here, though, that DeAngelo has been cleared in relation to two murder charges on the basis that his DNA did not match. ${ }^{68}$ As of April 2019 , there has been a further recent development in these proceedings, with prosecutors seeking to use the death penalty. ${ }^{69}$ Regardless of whether DeAngelo is ultimately convicted of the other charges against him, the manner in which this investigation was conducted should cause concern, especially in relation to privacy rights, but also in relation to other rights of suspects and innocent relatives, as well as how serious the consequences can be for individuals here. Since the Golden State Killer investigation coverage, it has emerged that a further 100 profiles from cold cases have been uploaded to GEDmatch and then in early 2019 the DTC company, FamilyTreeDNA, has revealed that it has been collaborating with the US Federal Bureau of Investigation (FBI) to investigate violent crime. ${ }^{70}$ These examples demonstrate the potential for genetic data collected by DTC companies to be used for secondary research purposes that might not be in consumers' best interests and could also impact upon their rights. It is vital to remember the premise of innocence until proof of guilt and also the right to a fair trial.

While law enforcement and other entities are likely to want to utilize new sources of data in investigations, we need to consider carefully how appropriate it is to use commercial private databases for criminal investigations. Given recent developments in research on DNA transfer, it is also important that investigators and courts are not overly reliant on DNA evidence, as it is quite possible for innocent people to leave DNA traces in places, on objects, and even on other people without their knowledge. The case of Lukis Anderson, who was wrongly charged due to DNA transfer, where his DNA was found on a murder victim he in fact never met, ${ }^{71}$ highlights the need for more caution and education here.

\footnotetext{
67 See Phillips, Buying Your Self on the Internet (n 1) ch 4, citing: M Thielking, 'Lawmakers Press Genetic Testing Companies for Details on Their Privacy Policies', STAT (21 June 2018), https://www.statnews.com/2018/ 06/21/congress-genetic-testing-companies-privacy-policies/ accessed 15 July 2019; R Becker, 'Golden State Killer Suspect Was Tracked Down through Genealogy Website GEDmatch', The Verge (26 April 2018), https:// www.theverge.com/2018/4/26/17288532/golden-state-killer-east-area-rapistgenealogy-websites-dna-geneticinvestigation accessed 15 July 2019; and T Hesman Saey, 'Why Using Genetic Genealogy to Solve Crimes Could Pose Problems', ScienceNews (7 June 2018), https://www.sciencenews.org/article/why-police-using-geneticgeneaology-solve-crimes-poses-problems?mode=pick\&context=2782\&tgt=nr accessed 15 July 2019; M Molteni, 'The Key to Cracking Cold Cases Might Be Genealogy Sites', Wired (1 June 2018), https://www.wired.com/story/ police-will-crack-a-lot-more-cold-cases-with-dna/ accessed 15 July 2019; GEDmatch, https://www.gedmatch. com/tos.htm accessed 15 July 2019.

68 T Lapin, “"Golden State Killer” Cleared of 1978 Double-Murder Cold Case', New York Post (14 June 2018), https://nypost.com/2018/06/14/golden-state-killer-cleared-of-1978-double-murder-cold-case/ accessed 15 July 2019; Associated Press, 'DNA Clears Accused Golden State Killer Joseph DeAngelo of 1975 Murder', NBC News (10 January 2019), https://www.nbcnews.com/news/us-news/dna-clears-accused-golden-state-killer-josephdeangelo-1975-murder-n956566?cid=sm_npd_nn_tw_ma accessed 15 July 2019.

69 D Smith and S Stanton, 'Prosecutors to Seek Death Penalty in Golden State Killer Case', The Mercury News (10 April 2019), https://www.mercurynews.com/2019/04/10/prosecutors-to-seek-death-penalty-in-goldenstate-killer-case/ accessed 15 July 2019; K Dowd, 'Golden State Killer Suspect Appears in Court Nearly One Year after Arrest', San Francisco Chronicle (10 April 2019), https://www.sfgate.com/bayarea/article/joseph-deangelohearing-sacramento-trial-13757418.php accessed 15 July 2019.

70 M Haag, 'FamilyTreeDNA Admits to Sharing Genetic Data with F.B.I.', The New York Times (4 February 2019), https://www.nytimes.com/2019/02/04/business/family-tree-dna-fbi.html accessed 15 July 2019.

${ }^{71}$ K Worth, 'Framed for Murder by His Own DNA', Wired (19 April 2018), https://www.wired.com/story/dnatransfer-framed-murder/ accessed 15 July 2019; see also RAH Van Oorschot and MK Jones, 'DNA Fingerprints from Fingerprints' (1997) 387(6635) Nature 767; and PA Smith, 'When DNA Implicates the Innocent' (2016) 314(16) Scientific American 11-12.
} 
If using commercial genetic databases for criminal investigation is to be permitted, there should be much more public discussion of the issues at stake. In the United Kingdom, it is also an offence under the Human Tissue Act to analyse DNA without appropriate consent and at present it is likely that the consent mechanisms used by DTC companies may not meet the requirements of either the GDPR or the Human Tissue Act.

\section{Conclusion}

In conclusion, the aim herein has been to draw attention to the impacts of electronic contracts and website design on the exercise of individual autonomy when making decisions about whether to purchase DTC genetic tests for health purposes. Given that most genetic tests for complex diseases have not yet been standardized and often lack clinical utility, allowing these services to be offered commercially without the involvement of physicians is concerning. When an individual has a genetic test in a medical clinic, they will have more support, especially in relation to understanding the implications of test results for their health, which is often not present with DTC services. There are also significant privacy risks in the context and wide potential for secondary use of genetic data by entities outside the health-care sector, which need more attention. It is also hoped that this chapter will encourage readers to think beyond this example to other new internet-based medical services and consider how we might approach things differently. Although e-commerce has made many services much more available, given the complex nature of genetic tests for health purposes, and the special characteristics of sequenced genetic data, taking a more cautious approach to governance in this context is desirable. 